\title{
Occurrence and expression of glutathione-S- transferase-encoding bphK genes in Burkholderia sp. strain LB400 and other biphenyl-utilizing bacteria
}

\author{
Frank Bartels, Silke Backhaus, Edward R. B. Moore, Kenneth N. Timmis \\ and Bernd Hofer
}

Author for correspondence: Bernd Hofer. Tel: +49 531 6181467. Fax: +49 5316181411.

National Research Centre for Biotechnology (GBF), Division of Microbiology، Mascheroder Weg1, D38124 Braunschweig, Germany
The gene bphK of Burkholderia sp. strain LB400 has previously been shown to be located within the bph locus, which specifies the degradation of biphenyl (BP) and chlorobiphenyls, and to encode a glutathione S-transferase (GST) which accepts 1-chloro-2,4-dinitrobenzene (CDNB) as substrate. The specific physiological role of this gene is not known. It is now shown that the gene is expressed in the parental organism and that GST activity is induced more than 20-fold by growth of the strain on BP relative to succinate when these compounds serve as sole carbon source. Approximately the same induction factor was observed for 2,3-dihydroxybiphenyl 1,2-dioxygenase activity, which is encoded by the $5^{\prime}$-adjacent bphC gene. This suggests that the expression of bphK is coregulated with the expression of genes responsible for the catabolism of BP. A bphK probe detected only a single copy of the gene in strain LB400. A spontaneous BP- mutant of the organism neither gave a signal with the bphK probe nor showed CDNB-accepting GST activity, suggesting that this activity is solely encoded by bphK. Complementation of the mutant with a bph gene cluster devoid of bphK restored the ability to grow on BP, indicating that bphK is not essential for utilization of this carbon source. BphK activity proved to be almost unaffected by up to 100 -fold differences in proton concentration or ionic strength. The enzyme showed a narrow range with respect to a variety of widely used electrophilic GST substrates, accepting only CDNB. A number of established laboratory strains as well as novel isolates able to grow on BP as sole carbon and energy source were examined for BphK activity and the presence of a bphK analogue. CDNB assays, probe hybridizations and PCR showed that several, but not all, BP degraders possess this type of GST activity and/or a closely related gene. In all bacteria showing BphK activity, this was induced by growth on BP as sole carbon source, although activity levels differed by up to 10-fold after growth on BP and by up to 60-fold after growth on succinate. This resulted in a variation of induction factors between 2 and 30 . In the majority of $b_{p h K^{+}}$bacteria examined, the gene appeared to be part of LB400-like bph gene clusters. DNA sequencing revealed almost complete identity of $b p h K$ genes from five different bph gene clusters. These results suggest that bphK genes, although not essential, fulfil a strain-specific function related to the utilization of BPs by their host organisms. The usefulness of BphK as a reporter enzyme for monitoring the expression of catabolic pathways is discussed.

Keywords: aerobic bacteria, biphenyl catabolism, $b p h$ genes, glutathione $S$-transferase, 1-chloro-2,4-dinitrobenzene

Abbreviations: $\mathrm{BP}$, biphenyl; $\mathrm{BP}^{+-}$, phenotype able/unable to grow on biphenyl as sole carbon source; $\mathrm{CDNB}, 1$-chloro-2,4-dinitrobenzene; DBDO, 2,3dihydroxybiphenyl 1,2-dioxygenase; GST, glutathione S-transferase; PAH, polyaromatic hydrocarbon.

The EMBL accession numbers for the sequences determined in this work are AJ245981-AJ245985. 


\section{INTRODUCTION}

The $b p h$ locus of Burkholderia sp. strain LB400 has been characterized in detail (Erickson \& Mondello, 1992; Hofer et al., 1993, 1994). Unexpectedly, a gene $(b p h K)$ encoding a protein with significant sequence similarity to prokaryotic and eukaryotic glutathione $S$ transferases (GSTs; EC 2 .5 .1.18) was found at a central location within this gene cluster $(b p h A 1 A 2 A 3 A 4 B C K$ $H J I D)$ and GST activity of the gene product was demonstrated (Hofer et al., 1994).

GSTs form a family of heterogeneous, multifunctional enzymes which are found in animals, plants and microorganisms (Fahey \& Sundquist, 1991; Hayes \& Pulford, 1995). The best-studied GSTs are those from mammals, in which typically several isoenzymes are found (Mannervik, 1985; Pickett \& Lu, 1989). In most instances, their exact physiological functions are not known.

The majority of eukaryotic GSTs are believed to primarily be involved in cellular detoxification of substances of xenobiotic origin (Pickett \& Lu, 1989). Induction of their synthesis in response to the application of xenobiotics, for example certain polychlorobiphenyls or 2,4-dichlorophenoxyacetic acid, has been observed (Aoki et al., 1992; Fujita et al., 1994; Tanno \& Aoki, 1996). GSTs can enhance the aqueous solubility of hydrophobic xenobiotics by mediating coupling of the hydrophilic tripeptide GSH to such compounds. The resulting conjugates are then further metabolized and eventually excreted. Some GSTs appear to be involved in binding and transport of hydrophobic substances (Mannervik, 1985; Pickett \& Lu, 1989). Others show peroxidase activity with organic peroxides (Prohaska, 1980). Based on substrate specificity and primary structure, (potentially) cytosolic GSTs have been divided into six classes, alpha, mu, pi, sigma, theta and zeta (Hayes \& Pulford, 1995; Board et al., 1997); additionally, classes phi (Blocki et al., 1993) and delta (Toung et al., 1993) have been proposed.

Prokaryotic GSTs, however, do not fit into this scheme (Di Ilio et al., 1993). Some of these enzymes have been shown to possess peroxidase activity (Nishida et al., 1994), to act as epoxide thiolases (Arca et al., 1988; van Hylckama Vlieg et al., 1998), or to catalyse different essential reactions in the metabolism of compounds such as gentisate, dichloromethane, lignin or tetrachlorohydroquinone that can thereby serve as growth substrates for the respective microbes (Crawford \& Frick, 1977; La Roche \& Leisinger, 1990; Masai et al., 1993; Nohynek et al., 1996). The in vivo functions of other bacterial GSTs, such as BphK, remain obscure. To obtain more insight into the role of BphK, we examined the expression of its gene in the parental organism, Burkholderia sp. strain LB400, the response of $b p h K$ expression to growth of the bacterium on biphenyl (BP) and the requirement of the gene for utilization by the organism of BP as sole carbon source. Furthermore, we investigated the substrate range of the enzyme and the distribution of $b p h K$ genes and of BP-inducible 1-chloro- 2,4-dinitrobenzene (CDNB)-accepting GST activity in other strains able to use BP as sole carbon source.

\section{METHODS}

Bacterial strains, plasmids and culture conditions. Escherichia coli strains used were DH5 $\alpha$ (Grant et al., 1990), BL21(DE3)[pLysS] (Studier, 1991) and S17-1 (Simon et al., 1983). Recombinant plasmids used were pAIA61 (Hofer et al., 1994), pAIA63 and pFY741A. pAIA63 is a SacI deletion derivative of pAIA61 that only harbours the $b p h K$ gene. The construction of pFY741A is described below. E. coli strains were grown in LB medium (Sambrook et al., 1989) at $37^{\circ} \mathrm{C}$. Selection for plasmids was as follows: ampicillin $\left(200 \mu \mathrm{g} \mathrm{ml} \mathrm{m}^{-1}\right)$ for pAIA plasmids, chloramphenicol $\left(60 \mu \mathrm{g} \mathrm{m} \mathrm{m}^{-1}\right)$ for pLysS and pFY741A. The BP-utilizing micro-organisms used are listed in Table 1. Novel isolates were obtained from cultures that had recently been enriched from polluted sediments of two rivers in eastern Germany, the Elbe and the Spittelwasser, by growth on BP as sole carbon source (Blumenroth, 1997). Single colonies were streaked to purity on LB plates. A $\mathrm{BP}^{-}$mutant of Burkholderia sp. strain LB400 (LB400-M4) was obtained by repeated subculturing of the organism in Luria broth (Bopp et al., 1983). In the mutant, the $b p h$ locus has been deleted, as evidenced by PCR analysis. LB400-M4 and BP-utilizing microorganisms were grown at $30^{\circ} \mathrm{C}$ on $\mathrm{M} 9$ minimal medium (Sambrook et al., 1989) supplemented with $625 \mu \mathrm{M} \mathrm{MgSO}_{4}$, $330 \mu \mathrm{M} \mathrm{MgO}, 23 \mu \mathrm{M} \mathrm{FeSO}_{4}, 25 \mu \mathrm{M} \mathrm{CaCO}_{3}, 6 \cdot 3 \mu \mathrm{M} \mathrm{ZnSO}_{4}$, $6.3 \mu \mathrm{M} \mathrm{MnSO}_{4}, 1.3 \mu \mathrm{M} \mathrm{CuSO}_{4}, 1 \cdot 2 \mu \mathrm{M} \mathrm{CoSO}_{4}$ and $0.4 \mu \mathrm{M}$ $\mathrm{H}_{3} \mathrm{BO}_{3}$ as described by Bauchop \& Elsden (1960) with either succinate $(20 \mathrm{mM})$ or BP $(5 \mathrm{mM})$ as carbon source. For plates, $\mathrm{BP}$ was supplied as vapor by placing some crystals in the lid of a Petri dish.

Preparation of cell extracts. Recombinant E. coli BL21(DE3) strains were grown in ZY medium (Studier \& Moffat, 1986) with antibiotics (see above) at $37^{\circ} \mathrm{C}$ to an $\mathrm{OD}_{600}$ of $0 \cdot 7$. After induction with $0.4 \mathrm{mM}$ IPTG, the cultures were incubated at $37^{\circ} \mathrm{C}$ for $3 \mathrm{~h}$. After two cycles of centrifugation at $6000 \mathrm{~g}$ $\left(10 \mathrm{~min}\right.$ at $\left.4{ }^{\circ} \mathrm{C}\right)$ and resuspension in $0 \cdot 01 \mathrm{vol} .0 \cdot 1 \mathrm{M}$ Tris $/ \mathrm{HCl}$ buffer ( $\mathrm{pH} 7 \cdot 5)$, cells were disrupted in a French press (SLM Instruments) at 20000 p.s.i. (138000 kPa) Subsequently, cell debris was removed by a 45 min centrifugation at $48000 \mathrm{~g}$ $\left(4^{\circ} \mathrm{C}\right)$. BP-utilizing micro-organisms were grown in supplemented M9 minimal medium with $5 \mathrm{mM}$ BP (added as crystals to the medium) or $20 \mathrm{mM}$ succinate at $30^{\circ} \mathrm{C}$ to an $\mathrm{OD}_{600}$ of $0 \cdot 5-0 \cdot 7$. Cell extracts were obtained as described for the recombinant $E$. coli strains, except for Rhodococcus globerulus P6, which was disrupted as described by Asturias et al. (1994a). Protein concentrations of the extracts were determined with a kit (Bio-Rad) based on the method of Bradford (1976).

Enzyme activities. These were measured in $1 \mathrm{~cm}$ quartz cuvettes in a UV2100 Shimadzu spectrophotometer equipped with a temperature-controlled cuvette holder. GST activity was assayed by the method of Habig et al. (1974) at $25^{\circ} \mathrm{C}$, unless otherwise indicated. The standard reaction mixture $(600 \mu \mathrm{l})$ contained $0 \cdot 1 \mathrm{M}$ potassium phosphate buffer $(\mathrm{pH} 6 \cdot 5)$, 1.0 mM GSH, 1.0 mM CDNB and 10-60 $\mu$ l cell extract. Other buffers used (Fig. 1) were also $0 \cdot 1 \mathrm{M}$ at $\mathrm{pH}$ 6.5. The influence of temperature, salt concentration and $\mathrm{pH}$ were assayed with potassium phosphate buffer. Enzyme activity was calculated by using a molar absorption coefficient for the CDNB-GSH conjugate of $9600 \mathrm{M}^{-1} \mathrm{~cm}^{-1}$ at $340 \mathrm{~nm}$ (Habig et al., 1974). 2,3-Dihydroxybiphenyl 1,2-dioxygenase (DBDO) activity was assayed at $25^{\circ} \mathrm{C}$ in a volume of $600 \mu \mathrm{l}$ containing $50 \mathrm{mM}$ potassium phosphate buffer ( $\mathrm{pH} 7 \cdot 5), 0 \cdot 3 \mathrm{mM}$ 2,3-dihydroxy- 
Table 1. BP-utilizing micro-organisms used in this work

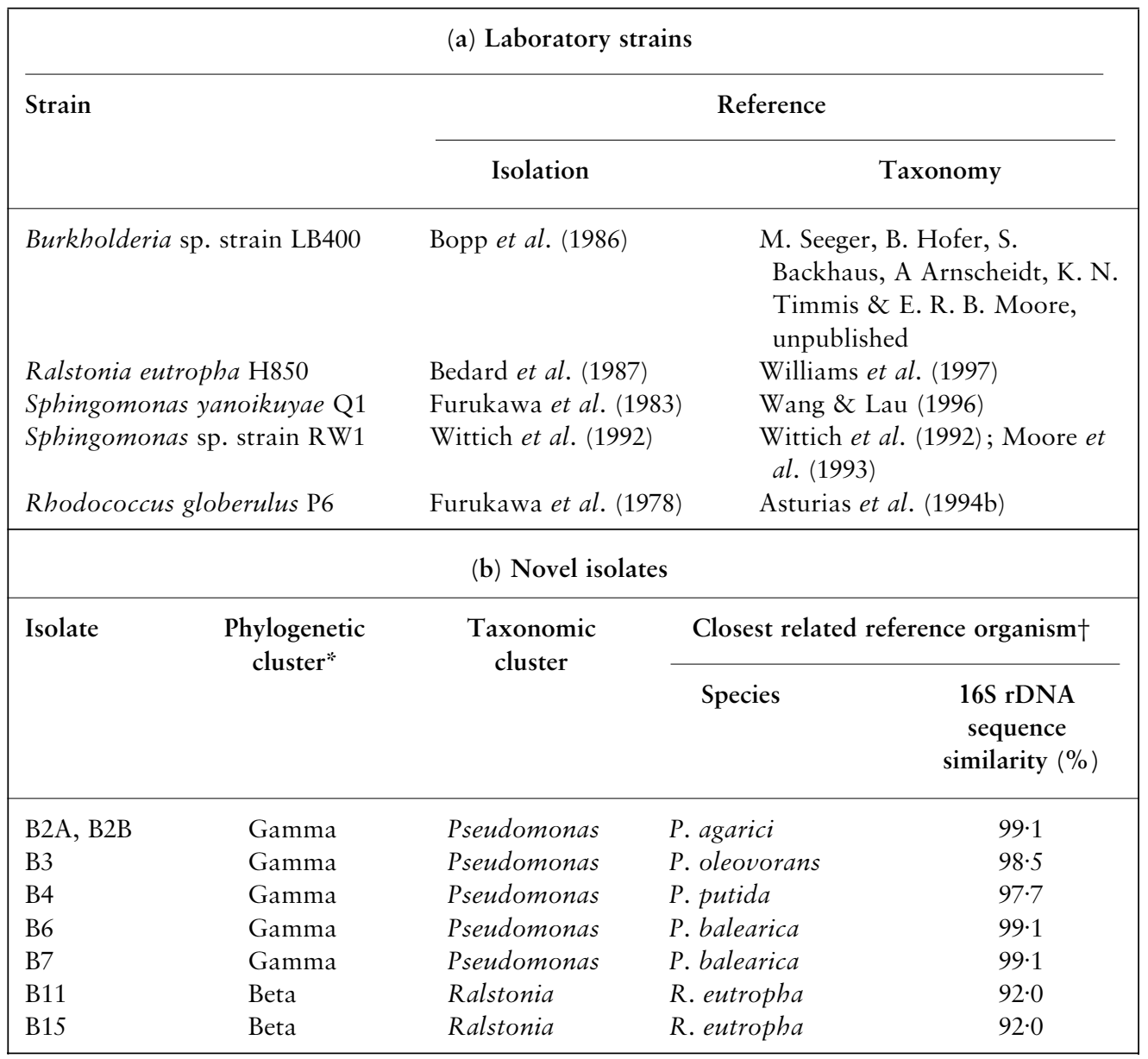

*Proteobacteria subclass.

† On the basis of $16 \mathrm{~S}$ rDNA sequence similarity (column 5).

biphenyl (supplied by Wako Chemicals) and 1-10 $\mu$ l of cell extract. Absorption was monitored at $434 \mathrm{~nm}$. Enzyme activity was calculated using a molar absorption coefficient for the meta-cleavage product of $13200 \mathrm{M}^{-1} \mathrm{~cm}^{-1}$ at $\mathrm{pH} 7 \cdot 5$ (Eltis et al., 1993). For both enzymes, one unit of activity was defined as the amount producing $1 \mu \mathrm{mol}$ product $\min ^{-1}$ at $25{ }^{\circ} \mathrm{C}$.

DNA isolation and digestion, gel electrophoresis, blotting and hybridization. Genomic DNA was isolated as described by Ausubel et al. (1994) unless otherwise indicated.

Procedures for agarose gel electrophoresis, staining, Southern blotting and restriction enzyme digestions were as described by Sambrook et al. (1989) unless otherwise specified. For dot blots, $0 \cdot 005-0 \cdot 1 \mu \mathrm{g}$ of genomic DNA were applied directly to a nylon membrane (Biodyne B; Pall). For Southern blots, digested genomic DNAs were separated in $0.8 \%(\mathrm{w} / \mathrm{v})$ agarose gels and transferred to nylon membranes with a Posiblot 30-30 Pressure Blotter (Stratagene). Hybridizations of probes (performed at $60^{\circ} \mathrm{C}$ with non-stringent washings at $45^{\circ} \mathrm{C}$ ) and their visualization were carried out with a digoxigenin-11dUTP kit (Boehringer Mannheim) as described in the manufacturer's instructions.

PCR amplification of bph genes, including synthesis of probes. PCR amplifications (Mullis \& Faloona, 1987) of $b p h$ genes were carried out in $50 \mu \mathrm{l}$ volumes and contained $100 \mathrm{ng}$ genomic DNA, $0.5 \mu \mathrm{M}$ of each primer, $0.2 \mathrm{mM}$ of each $\mathrm{dNTP}$ (Pharmacia), $1.5 \mathrm{U}$ Taq DNA polymerase (Boehringer Mannheim) and $0 \cdot 1$ vol. $10 \times$ Taq buffer supplied with the polymerase, under 2 drops of mineral oil. Amplifications were performed in a thermal cycler (Landgraf TC Varius V) programmed for one cycle of $120 \mathrm{~s}$ at $95^{\circ} \mathrm{C}, 40$ cycles at $95^{\circ} \mathrm{C}$ (30 s), $50{ }^{\circ} \mathrm{C}\left(30 \mathrm{~s}\right.$, with an increment of $3 \mathrm{~s}$ per cycle), $72^{\circ} \mathrm{C}$ ( $60 \mathrm{~s}$, with an increment of $3 \mathrm{~s}$ per cycle) and a final incubation for $10 \mathrm{~min}$ at $72{ }^{\circ} \mathrm{C}$. Products were separated electrophoretically in $1 \%(\mathrm{w} / \mathrm{v})$ agarose gels. The following primers were used: PK1 (5'-TACTACAGCCCTGGTGCC-3'), PK2 (5'-GTATTGCACGATGGCCGG-3'), PK3 (5'-CGAGCACGACGAACAGATAG-3'), PK4 (5'-CTCCTTGATCAAGCCTTCGG-3'), PC1 (5'-TAGAGGTCGAGTATGGCTGG$\left.3^{\prime}\right)$, PH1 (5'-CATCCGTTGCTGAATGTGG-3'), PS4D (5' ATCGCCGTTCAGCAGGGCGA-3'), PS4U (5'-CTCCAGCCATACTCGACCTC-3'), PS5D (5'-GCATGGCGCAGTTATGCTG-3') and PS5U (5'-TTGCAGTGCATGAAGTAC-3'). The latter four primers were sythesized according to sequences designed previously (Erb \& Wagner-Döbler, 1993). Probes were labelled using a digoxigenin-11-dUTP kit (Boehringer Mannheim). The $b p h K$ probe (207 bp) was synthesized using PK1 and PK2. The LB400 $b p h C$ probe (643 bp) was obtained with PS4D and PS4U. The Q1 $b p h C$ probe (523 bp) was 
synthesized using PS5D and PS5U. Probes were used for hybridization without further purification. For combinations of primers used in analytical PCRs and for locations of their target sequences in $b p h C K H$ of strain LB400 see Results and Fig. 2.

Complementation analysis of a LB400 $\mathrm{BP}^{-}$mutant. The mobilizable broad-host-range plasmid pFY741A containing LB400 bphA1A2A3A4BCDHJI was constructed as follows. $b p h H J I$ were amplified by PCR (see above) using primers introducing $K p n I$ sites. The $K p n I$-cleaved product was inserted into the KpnI site of pAIA74 (Hofer et al., 1994) downstream of $b p h D$ to yield pAIA741, which contained the insert in the sense orientation. $b p h A 1 A 2 A 3 A 4 B C D H J I$ were excised from pAIA741 as a NotI fragment and inserted into NotI-cleaved pIMP2072, a derivative of pMMB207 (Morales et al., 1991) with an extended multiple cloning site (unpublished) to yield pFY741A, which contained the insert in the sense orientation with respect to $\mathrm{P}_{\text {tac }}$ of the vector. pFY741A was transferred to the $\mathrm{BP}^{-}$mutant LB400-M4 by conjugation with the E. coli donor strain S17-1 using a standard filter-mating technique (Simon et al., 1983). Mating mixtures were plated on supplemented minimal agar (see above) with BP as carbon source. Controls were carried out with mixtures devoid of pFY741A.

Determination of $\boldsymbol{b p h}$ gene sequences. PCR-amplified $b p h$ gene segments were sequenced as described in the next section. The primers used were PC1, PK1, PK3 and PK4 (see above).

Determination of $16 \mathrm{~S}$ rDNA sequences. Genomic DNA was extracted from 1-5 colonies picked from agar plates by resuspension in $100 \mu \mathrm{l} 10 \mathrm{mM}$ Tris $/ \mathrm{HCl}, 1 \mathrm{mM}$ EDTA $(\mathrm{pH}$ $8 \cdot 0$ ), heating at $95{ }^{\circ} \mathrm{C}$ for $5 \mathrm{~min}$ and removal of cell debris by a brief centrifugation. Supernatant $(1 \mu \mathrm{l})$, containing genomic DNA, was added to a PCR mixture (Mullis \& Faloona, 1987) for amplification of bp 28-519 of $16 \mathrm{~S}$ rRNA genes using a GeneAmp PCR System 9600 (Perkin-Elmer) and reaction conditions as reported previously (Karlson et al., 1993). PCRrDNA was purified using Centricon-100 microconcentrators (Amicon) and sequenced using an Applied Biosystems 373A DNA Sequencer and the protocol of the manufacturer (Perkin Elmer, Applied Biosystems Division) for ' $T a q$ cyclesequencing' with fluorescent dye-labelled dideoxynucleotides. The sequencing primers have been described by Lane (1991). Sequence data were aligned with reference rRNA and rDNA sequences (Maidak et al., 1997; Stoesser et al., 1997) using evolutionarily conserved primary and secondary structures as reference (Woese et al., 1983; Gutell et al., 1985). Sequence similarities were calculated for sequence pairs using unambiguously determined nucleotide positions.

Computational methods. Database searches and binary amino acid sequence alignments were carried out at the National Center for Biotechnology Information, Bethesda, MD, USA, using programs BLASTN, TBLASTN, or BLASTP (Altschul et al., $1990,1997)$. Alignments were performed using the BLosum62 comparison matrix (Henikoff \& Henikoff, 1992) with the following parameters: open gap cost, 11; gap extension cost, 1.

\section{RESULTS}

\section{Substrate range of BphK and influence of physico- chemical parameters on enzyme activity}

The dependence of BphK activity on ionic strength, type of buffer, $\mathrm{pH}$ value and temperature was determined with extracts of a recombinant E. coli B strain expressing $b p h K$ (Fig. 1). Although CDNB-accepting GST activities have been reported for E. coli B and K-12 (Iizuka et al., 1989; Nishida et al., 1994), no background activity of the host strain was observed. At pH 6.5, BphK showed only minor differences in substrate turnover rate with potassium phosphate concentrations varying 100 -fold, i.e. between $10 \mathrm{mM}$ and $1 \mathrm{M}$. Similar variations, observed with three types of buffers, appear to largely reflect the ionic strength differences of these buffers. Enzyme activity showed a broad $\mathrm{pH}$ optimum ranging from 6.0 to $8 \cdot 0$. With respect to temperature dependence, maximal activity was found around $55^{\circ} \mathrm{C}$. These results indicate that the enzyme retains its active form over a fairly wide range of conditions.

BphK had previously been shown to catalyse formation of a GSH conjugate with the so-called universal GST substrate CDNB (Hofer et al., 1994). The substrate spectrum of the enzyme was investigated using six other compounds frequently accepted by GSTs, namely 1,2dichloro-4-nitrobenzene, 4-nitropyridine $\mathrm{N}$-oxide, $\mathrm{p}$ nitrobenzyl chloride, bromosulphophthalein, trans-4phenyl-3-buten-2-one and 2,3-dichloro-4-(2-methylene1-oxobutyl)phenoxyacetic acid (ethacrynic acid). None of these compounds was found to be converted into a GSH conjugate, suggesting that the enzyme has a relatively narrow substrate range.

\section{Relationship between CDNB-accepting GST activity of strain LB400 and its bphK gene}

Strain LB400 was examined by Southern hybridization of EcoRI-digested DNA with a gene probe derived from the $5^{\prime}$-terminal part of $b p h K$ (Fig. 2). A single strong band (see Fig. 5, lane 8) and two extremely faint bands were observed. The weak bands may not necessarily be due to lower similarity GST genes, but could, for example, result from genes encoding other types of GSH-binding proteins as the probe was directed against the gene segment encoding the GSH-binding domain (Xinhua et al., 1992). The strong band observed corresponded to a fragment size of $6.6 \mathrm{kbp}$, which agrees with the sequence data for the $b p h$ locus of strain LB400 (Erickson \& Mondello, 1992; Hofer et al., 1994).

A spontaneous mutant of strain LB400 that had lost the ability to grow on BP as sole source of carbon and energy did not yield the strong probe signal (not shown). In contrast to the wild-type strain (see below), the mutant did not show GST activity after growth on succinate. These results suggest that the CDNBaccepting GST activity of strain LB400 is solely specified by $b p h K$.

\section{Requirement for bphK for growth of strain LB400 on biphenyl}

The mobilizable plasmid pFY741A containing LB400 genes $b p h A 1 A 2 A 3 A 4 B C D H J I$, but devoid of $b p h K$, was transferred to the $\mathrm{BP}^{-}$mutant of strain LB400. Transconjugants were obtained that had regained the ability to grow on $\mathrm{BP}$, whilst spontaneous revertants to the $\mathrm{BP}^{+}$ 

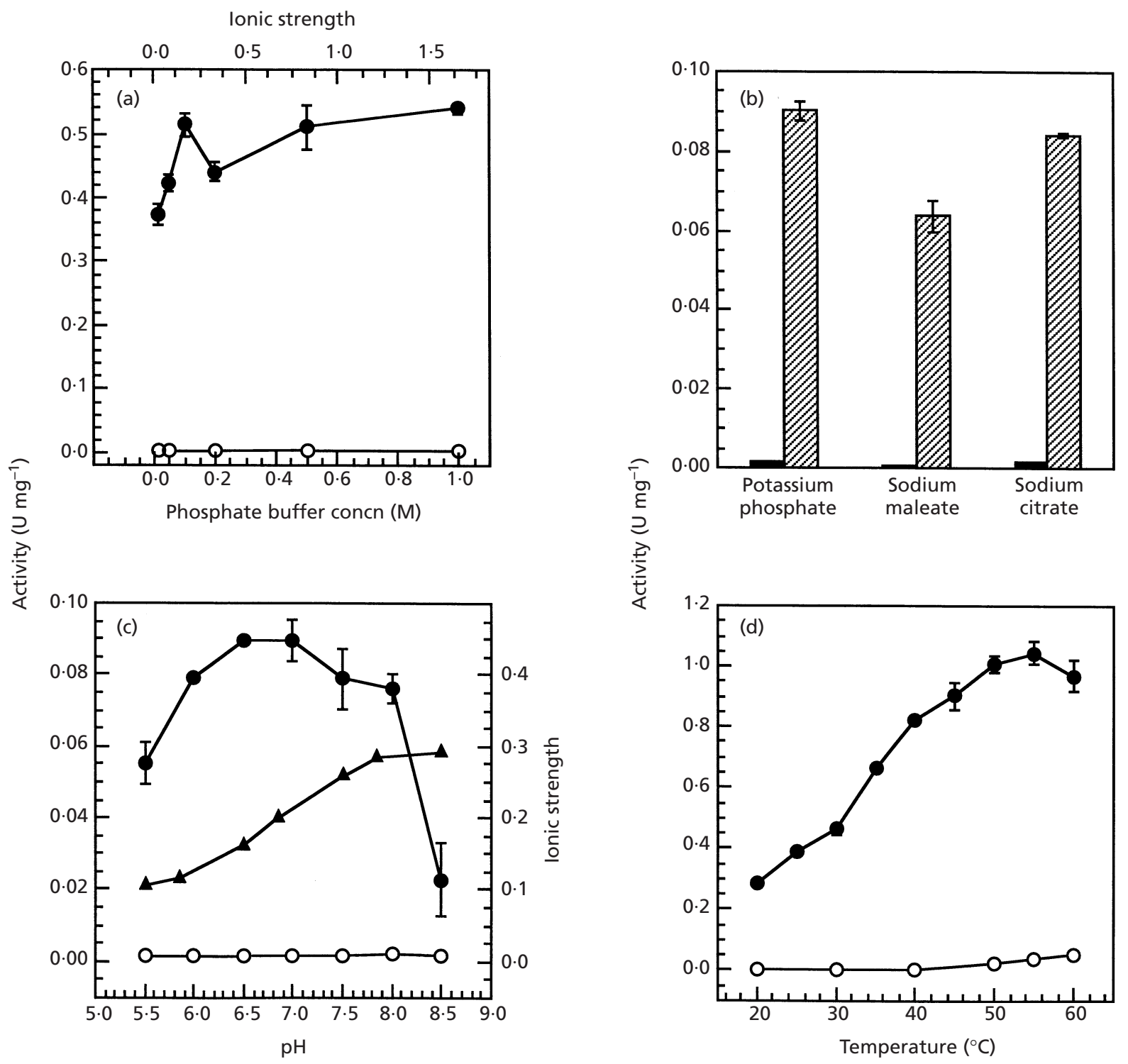

Fig. 1. Effect of assay conditions on activity of BphK from strain LB400. (a) lonic strength (potassium phosphate, pH 6.5); (b) type of buffer [buffer concentrations $(0.1 \mathrm{M}$ at $\mathrm{pH} 6.5)$ correspond to ionic strengths of approx. 0.17 (potassium phosphate), 0.25 (sodium maleate) and 0.56 (sodium citrate)]; (c) $\mathrm{pH}$ value $(0.1 \mathrm{M}$ potassium phosphate); (d) temperature $\left(0.1 \mathrm{M}\right.$ potassium phosphate; $\mathrm{pH}$ variation between $20^{\circ} \mathrm{C}$ and $60^{\circ} \mathrm{C}, 6.50-6 \cdot 34$; ionic strength variation between $20^{\circ} \mathrm{C}$ and $60^{\circ} \mathrm{C}, 0 \cdot 17-0 \cdot 15$ ). Filled circles and hatched columns, cell extracts of $E$. coli BL21(DE3)[pLysS] harbouring the pT7-6-derived plasmids pAIA63 $(a, d)$ or pAIA61 (b, c) which contain bphK under the control of a T7 promoter. Open circles and filled columns, cell extracts of $E$. coli BL21(DE3)[pLysS] harbouring pT7-6. Filled triangles (c), ionic strength of buffer. Results shown are means \pm SEM of three measurements.

phenotype were not observed. This indicates that $b p h K$ is not essential for utilization of this carbon source by strain LB400.

\section{Analysis of strain LB400 and other $\mathrm{BP}^{+}$bacteria for CDNB-accepting GST activity and its inducibility by growth on BP}

The location of $b p h K$ in the centre of a gene cluster encoding enzymes for the utilization of BP as carbon source (Fig. 2) suggests that its expression is induced by this compound or its metabolites. GST activity was quantified after growth of strain LB400 on BP or succinate as sole carbon source (Table 2). Activity was found under both conditions, but the level of specific activity was approximately 20 -fold higher after growth on BP.

$b p h K$ is located directly downstream of $b p h C$ (Fig. 2), which encodes a ring-cleaving DBDO that catalyses the third step of aerobic BP catabolism (Catelani et al., 1973). The ratios of GST and DBDO activities after 


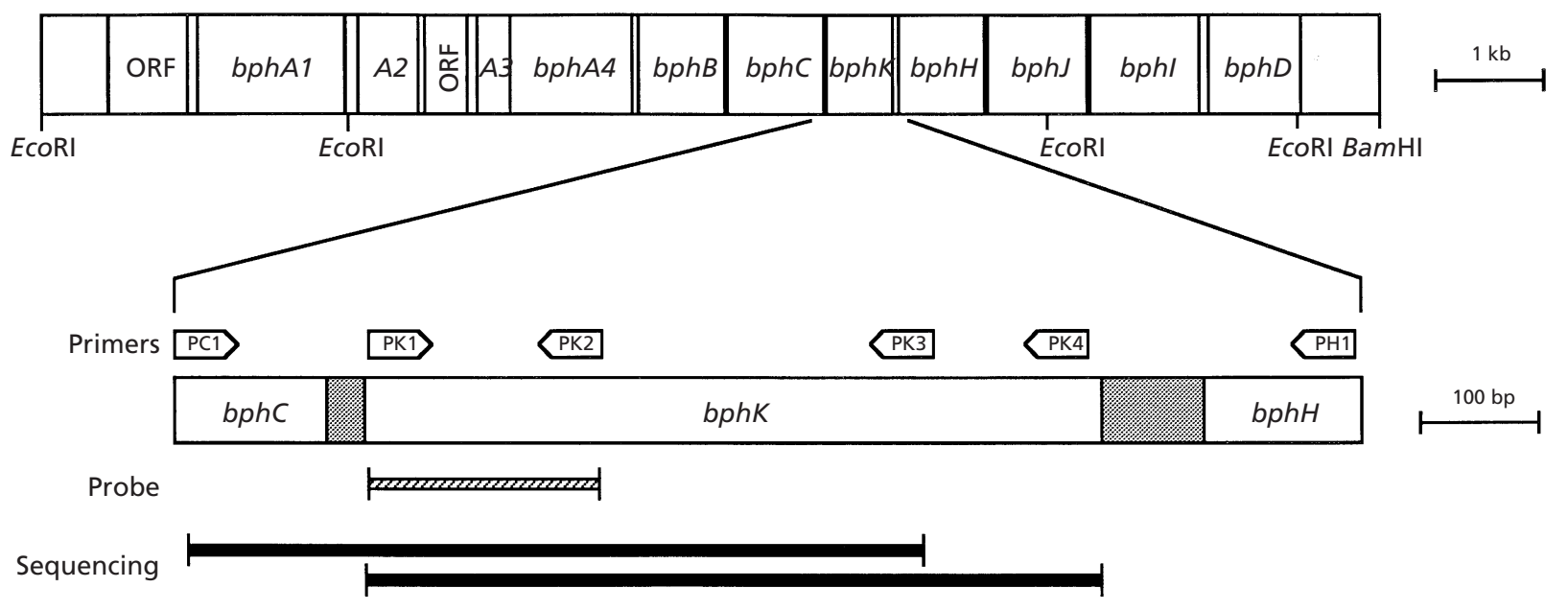

Fig. 2. Location within the LB400 $b p h$ locus of the $b p h K$ probe, of PCR primers used for $b p h K$ analysis and of sequenced regions. Genes encode the following enzymes: bphA1A2A3A4, biphenyl 2,3-dioxygenase system; bphB, biphenyl-2,3dihydro-2,3-diol dehydrogenase; $b p h C$, DBDO; $b p h K, \mathrm{GST} ; b p h H$, 2-hydroxypenta-2,4-dienoate hydratase; bphJ, acetaldehyde dehydrogenase (acylating); bphl, 4-hydroxy-2-oxovalerate aldolase; $b p h D$, 2-hydroxy-6-oxo-6-phenylhexa2,4-dienoate hydrolase.

Table 2. GST and DBDO activities in crude extracts of bacterial strains after growth on BP or succinate (Su)

\begin{tabular}{|c|c|c|c|c|c|c|}
\hline \multirow[t]{2}{*}{ Strain } & \multicolumn{3}{|c|}{ GST } & \multicolumn{3}{|c|}{ DBDO } \\
\hline & $\begin{array}{c}\text { Activity } \\
\text { BP }^{*}\end{array}$ & $\begin{array}{c}\text { Activity } \\
\text { Su* }\end{array}$ & $\begin{array}{l}\text { Ratio } \\
\mathrm{BP} / \mathrm{Su}\end{array}$ & $\begin{array}{c}\text { Activity } \\
\text { BP* }\end{array}$ & $\begin{array}{c}\text { Activity } \\
\text { Su* }^{*}\end{array}$ & $\begin{array}{l}\text { Ratio } \\
\mathrm{BP} / \mathrm{Su}\end{array}$ \\
\hline LB400 & $21 \cdot 2 \pm 0 \cdot 7$ & $1 \cdot 1 \pm 0 \cdot 1$ & 19 & $3080 \pm 210$ & $119 \pm 1 \cdot 0$ & 26 \\
\hline H850 & $20 \cdot 2 \pm 1 \cdot 0$ & $0 \cdot 7 \pm 0 \cdot 1$ & 29 & $2760 \pm 100$ & $58 \cdot 8 \pm 1 \cdot 8$ & 47 \\
\hline Q1 & $17 \cdot 3 \pm 0 \cdot 2$ & $0 \cdot 6 \pm 0 \cdot 1$ & 29 & $23 \cdot 2 \pm 0 \cdot 9$ & $24 \cdot 5 \pm 0 \cdot 6$ & 1 \\
\hline P6 & $\mathrm{NF}$ & ND & NA & ND & ND & NA \\
\hline RW1 & NF & ND & NA & ND & ND & NA \\
\hline B2A & $64 \cdot 3 \pm 2 \cdot 4$ & $35 \cdot 8 \pm 1 \cdot 3$ & 2 & $4070 \pm 150$ & $43 \cdot 9 \pm 7 \cdot 0$ & 93 \\
\hline B2B & $155 \pm 5 \cdot 0$ & $26 \cdot 9 \pm 0 \cdot 7$ & 6 & $8500 \pm 200$ & $78 \cdot 3 \pm 8 \cdot 5$ & 110 \\
\hline B3 & $15 \cdot 9 \pm 0 \cdot 6$ & $2 \cdot 6 \pm 0 \cdot 1$ & 6 & $\mathrm{NF}$ & $259 \pm 7$ & NA \\
\hline B4 & $23 \cdot 5 \pm 0.5$ & $3 \cdot 1 \pm 0 \cdot 2$ & 8 & $\mathrm{NF}$ & $\mathrm{NF}$ & NA \\
\hline B6 & $62 \cdot 3 \pm 1 \cdot 7$ & $5 \cdot 2 \pm 0 \cdot 4$ & 12 & $\mathrm{NF} \dagger$ & $\mathrm{NF}$ & NA \\
\hline B7 & $52 \cdot 3 \pm 2 \cdot 9$ & $11 \cdot 9 \pm 0 \cdot 3$ & 4 & NF† & $\mathrm{NF}$ & NA \\
\hline B11 & $\mathrm{NF}$ & ND & NA & $\mathrm{ND}$ & ND & NA \\
\hline B15 & $\mathrm{NF}$ & ND & NA & $\mathrm{ND}$ & ND & NA \\
\hline
\end{tabular}

NF, Not found; ND, not determined; NA, not applicable.

* Results expressed in $\mathrm{nmol} \mathrm{mg}^{-1} \mathrm{~min}^{-1}$.

† Activity detected with solid 2,3-dihydroxybiphenyl.

growth of the strain on BP or succinate were found to be similar (Table 2), indicating that the expression of both genes is subject to the same control mechanism and consistent with the view that both genes are cotranscribed.

To gain insight into the distribution of similar GST activity in other BP-degrading bacteria, a number of randomly chosen strains able to use $\mathrm{BP}$ as sole carbon and energy source were investigated. Some of them were well-known laboratory strains, others were recently isolated (Blumenroth, 1997) from polluted sediments of two rivers in eastern Germany, the Elbe and the Spittelwasser (Table 1). A taxonomic characterization of the new isolates was carried out by $16 \mathrm{~S} \mathrm{rDNA}$ sequencing. It revealed that they belong to the genera Pseudomonas and Ralstonia and represent five different species (Table 1). The taxonomic relationship of all 


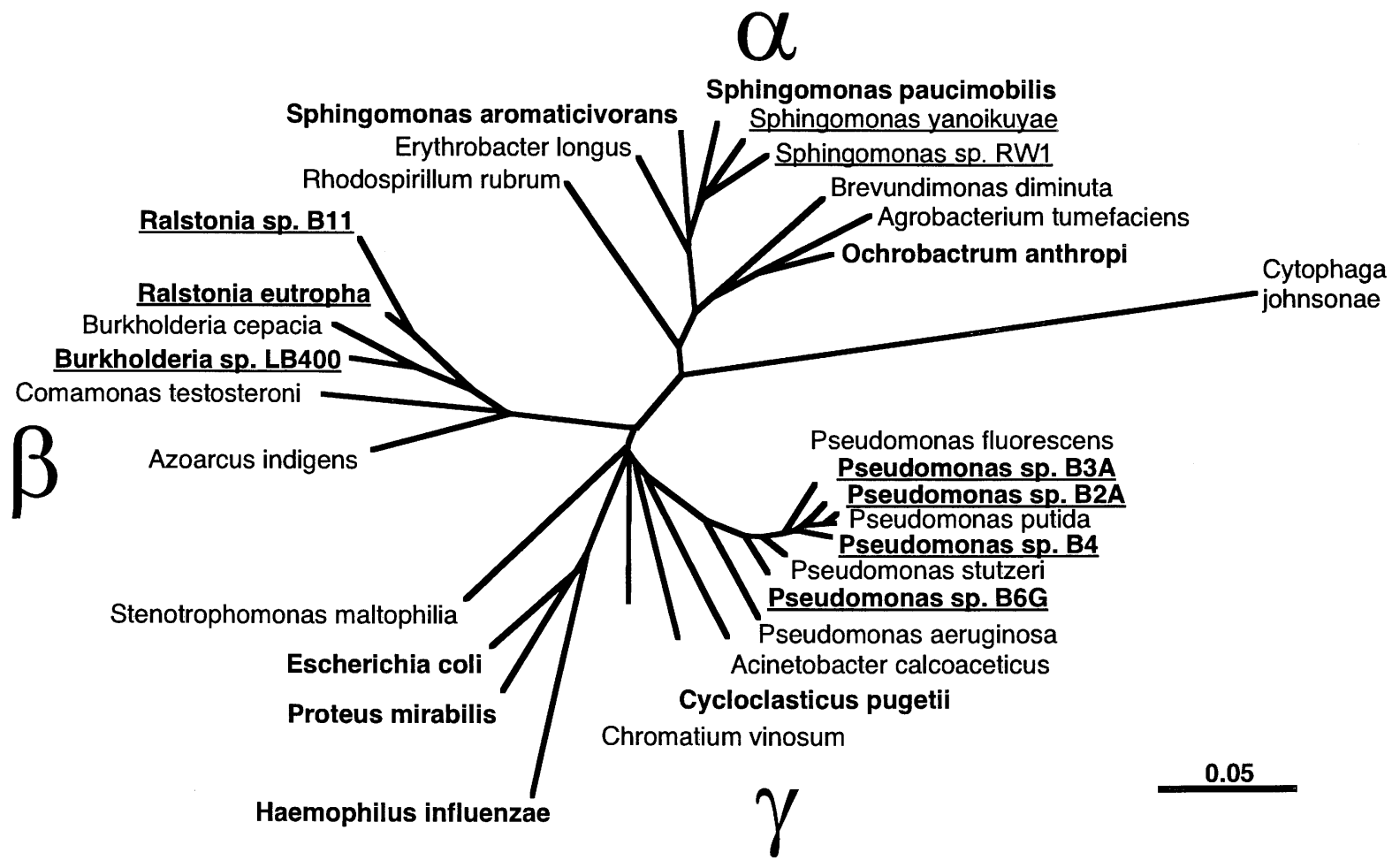

Fig. 3. Phylogenetic tree of proteobacteria based on $16 \mathrm{~S}$ rDNA sequences. $\alpha, \beta$ and $\gamma$ sub-classes are indicated. Cytophaga johnsonae was used as outgroup. The bar indicates the scale of estimated evolutionary distance, i.e. a mean of 5 substitutions at any nucleotide position, per 100 nucleotide positions, of the 16S rRNA genes. Species or specific organisms used in this work are underlined. Species or specific organisms known to encode GSTs with a relatively high degree of sequence identity to BphK from strain LB400 are highlighted in boldface. As a 16S rDNA sequence for 'Cycloclasticus oligotrophus' is not yet available, Cycloclasticus pugetii was included instead.

Gram-negative strains used in this work is illustrated in Fig. 3.

A total of 13 micro-organisms, including strain LB400, were assayed for CDNB-accepting GST activity after growth on BP. Nine of them yielded a positive result (Table 2). Specific GST activities varied by as much as one order of magnitude. They differed even up to 50-fold after growth of the strains on succinate, but were always lower under these conditions (Table 2). The positive BPdependence of the GST activities suggests that they at least partly reflect the expression of GST genes that are linked to genes involved in BP catabolism.

Induction of GST activity was again compared to that of DBDO activity of the strains (Table 2). However, quantification of the latter proved to be difficult with several of the bacteria. Sometimes activity could not be detected at all in the standard assay. Rapid turnover of the ring fission product could account for this problem. Consistent with this view, a yellow metabolite, presumably the ring fission product, was sometimes transiently observed when a large excess of solid substrate was added to whole cells or cell extracts of strains that had not shown activity under standard conditions. Except for strain LB400, no correlation was found between the induction ratios of GST and DBDO activities. These results could be due to the problems in

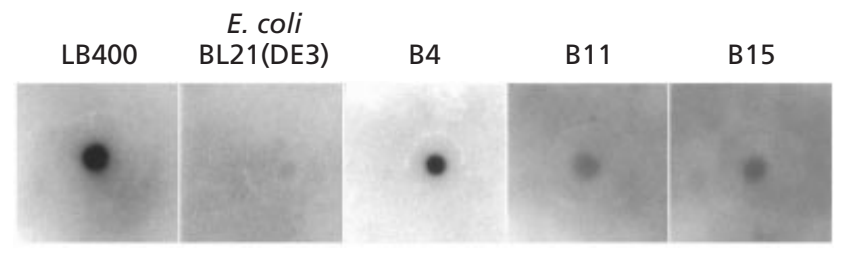

Fig. 4. Dot blot analysis of selected strains using a $207 \mathrm{bp} b p h K$ fragment as probe. For each dot $0 \cdot 1 \mu \mathrm{g}$ genomic DNA was applied.

DBDO activity measurement. The data presented in the following section indicate that in most of the strains $b p h C$ genes are indeed located upstream of $b p h K$ genes.

\section{Analysis of strain LB400 and other $\mathrm{BP}^{+}$bacteria for the occurrence and relative location of $b p h K$-like genes}

The randomly chosen BP-degrading bacteria were screened in dot blots with the $b p h K$ probe described above. Some representative results are illustrated in Fig. 4; an overview is given in Table 3. Clear signals were obtained with seven strains, all of which had GST activity (above). Weak dots were observed with strains Q1, B11 and B15, although no GST activity had been 
Table 3. Examination of occurrence and location of $b p h K$ genes in bacterial strains

\begin{tabular}{|c|c|c|c|c|c|c|c|}
\hline \multirow[t]{2}{*}{ Strain } & \multirow{2}{*}{$\begin{array}{l}\text { Dot blots } \\
\text { bphK probe }\end{array}$} & \multicolumn{2}{|c|}{ Southern blots $\dagger$} & \multicolumn{4}{|c|}{ PCR analysis $\ddagger$} \\
\hline & & bphK probe & bphC probe & bphK & bphCK & bphKH & bphCH \\
\hline LB400 & ++++ & $6 \cdot 6(5 \cdot 6,4 \cdot 2)$ & $6 \cdot 6$ & ++ & ++ & $++\mathrm{B}$ & ++ \\
\hline H850 & ++++ & $6 \cdot 6(5 \cdot 6,4 \cdot 2)$ & $6 \cdot 6$ & ++ & ++ & ++ & ++ \\
\hline Q1 & ++ & $4 \cdot 2$ & $2 \cdot 4,1 \cdot 7$ & - & - & - & - \\
\hline P6 & - & ND & ND & ND & ND & ND & ND \\
\hline RW1 & - & ND & ND & ND & $\mathrm{ND}$ & $\mathrm{ND}$ & ND \\
\hline B2A & ++++ & $6 \cdot 6(5 \cdot 6,4 \cdot 2)$ & $6 \cdot 6$ & $++\mathrm{B}$ & ++ & ++ & $++\mathrm{B}$ \\
\hline $\mathrm{B} 2 \mathrm{~B}$ & ++++ & $6 \cdot 6(5 \cdot 6,4 \cdot 2)$ & $6 \cdot 6$ & ++ & ++ & ++ & ++ \\
\hline $\mathrm{B} 3 \mathrm{~B} \mathbb{S}$ & ++++ & $6 \cdot 6(5 \cdot 6,4 \cdot 2)$ & $6 \cdot 6$ & ++ & ++ & $++\mathrm{B}$ & ++ \\
\hline B4 & ++++ & $6 \cdot 6(17,5 \cdot 6)$ & $6 \cdot 6$ & ++ & $++\mathrm{B}$ & ++ & ++ \\
\hline B6G $\mathbb{S}$ & ++++ & $8 \cdot 0$ & $8 \cdot 0$ & ++ & $++\mathrm{B}$ & ++ & ++ \\
\hline B7T $\$$ & +++ & $8 \cdot 0$ & $8 \cdot 0$ & ++ & ++ & ++ & ++ \\
\hline B11 & ++ & $\mathrm{ND}$ & ND & $+\mathrm{B} \|$ & $+\mathrm{B} \|$ & - & $+\mathrm{B} \|$ \\
\hline B15 & ++ & $\mathrm{ND}$ & ND & - & $+B$ & - & $+\mathrm{B}$ \\
\hline BL21 & + & $\mathrm{NF}$ & $\mathrm{NF}$ & ND & ND & ND & ND \\
\hline DH5 $\alpha$ & - & $\mathrm{ND}$ & $\mathrm{ND}$ & $\mathrm{ND}$ & $\mathrm{ND}$ & ND & $\mathrm{ND}$ \\
\hline
\end{tabular}

ND, Not determined; NF, not found.

*Symbols indicate signal intensity as follows: ++++ , strong; +++ , moderate; ++ , weak; + , very weak; - , not visible.

† Numbers give the lengths of observed fragments in kbp. Very weak signals are given in parentheses. $\ddagger$ Primers consist of LB400 sequence of the $b p h$ genes indicated below. The following combinations were used: $b p h K, \mathrm{PK} 1+\mathrm{PK} 2,3,4 ; b p h C K, \mathrm{PC} 1+\mathrm{PK} 2,3,4 ; b p h K H, \mathrm{PK} 1+\mathrm{PH} 1 ; b p h C H, \mathrm{PC} 1+\mathrm{PH} 1$. For $b p h K$ and $b p h C K$, the most positive result of the three PCR reactions is given. ++ , Strong band of mobility observed with LB400; +, weak band of mobility observed with LB400; -, no band of mobility observed with LB400; B, by-products observed.

\$During the course of this work, isolates B3, B6 and B7 were further resolved into two or three individual strains. As all of the newly resolved strains showed no differences in all assays carried out, the results for only one isolate are given in the table.

$\|$ Further investigated by nested PCR.

detected with the latter two. No probe hybridization was detected with strains P6 and R W1, which also were GST-negative. The E. coli $\mathrm{K}-12$ strain $\mathrm{DH} 5 \alpha$ and the $E$. coli B strain BL21(DE3)[pLysS], assayed as controls, did not give rise to significant signals. An alignment of $b p h K$ with the sequenced GST gene from E. coli K-12 (Nishida et al., 1994) yielded an approximately $60 \%$ identity in the region spanned by the probe (not shown). This agrees with the experimental result, as such a degree of homology normally is too low for a probe to stably anneal.

The seven strains that had yielded strong signals and the GST-positive strain Q1 were examined by Southern hybridization with EcoRI-digested DNA (Fig. 5). Only a single band of each strain gave rise to a strong or moderate (strain Q1) signal. As with strain LB400, two very faint additional bands were observed with some strains (Table 3).

The Southern blots were rehybridized with $b p h C$ probes derived from strains LB400 or Q1 (Table 3). The LB400 probe yielded a single strong signal with all DNAs except for that of strain Q1. It annealed, on the basis of fragment mobility, to the same fragments as the $b p h K$ probe, suggesting that both genes belong to the same cluster. The Q1 probe annealed to two DNA fragments of strain Q1, in agreement with the presence of an EcoRI site within its $b p h C$ gene (Taira et al., 1988). However, neither of these two fragments corresponded to the fragment containing the $b p h K$ analogue.

PCR was used to locate the $b p h K$ analogues more precisely relative to potentially adjacent $b p h$ genes. Primers were derived from $b p h C, b p h H$ and $b p h K$ of strain LB400 (Fig. 2). An overview of the PCR data is given in Table 3. No PCR products were obtained from strain Q1. The other strains that had given signals in Southern blots yielded fragments of the same sizes as LB400. Typical results are presented for strain B6B in comparison with strain LB400 in Fig. 6. These data indicate a significant similarity between the $b p h$ gene clusters of the positive strains and the $b p h$ locus of LB400. Strains B11 and B15, which had shown no GST activity but weak signals in dot blot hybridization, gave rise to various bands in PCR. These included very faint bands with the mobility of the corresponding products from strain LB400. Three such PCRs with DNA from B11 (Fig. 6c, lanes 2, 5 and 8) were used as templates in 


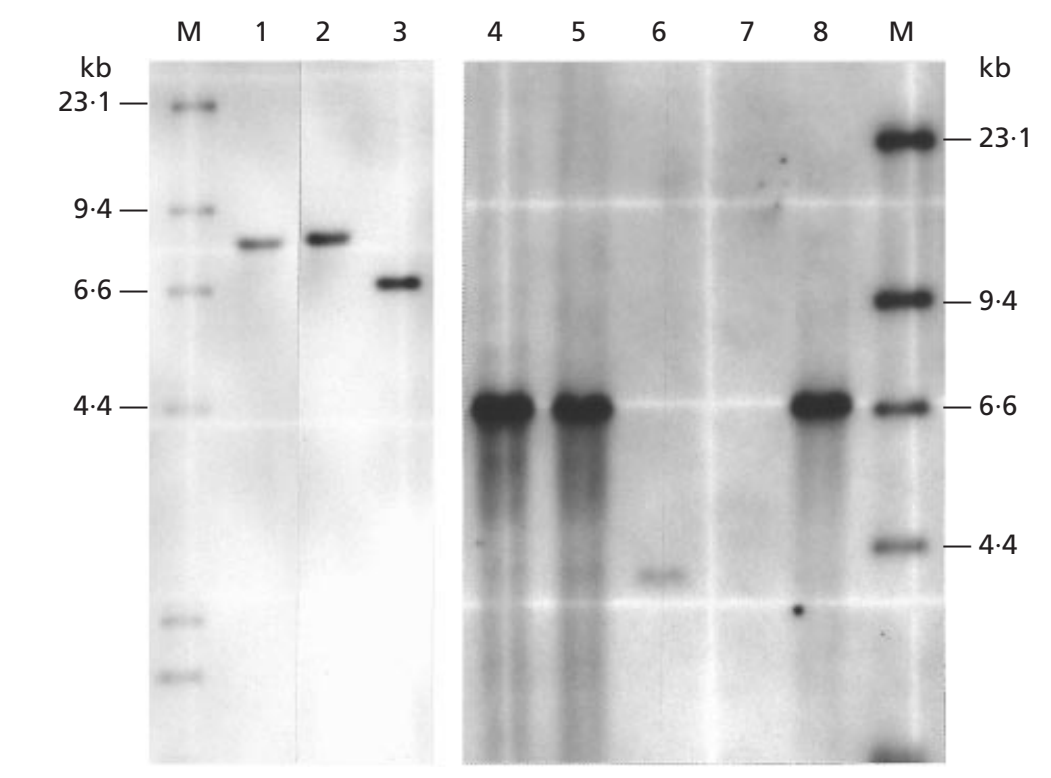

Fig. 5. Southern hybridization analysis of EcoRI-digested genomic DNA of different strains using the bphK probe. Lanes: $M$, digoxigenin-labelled molecular mass marker II (Boehinger Mannheim); 1, Pseudomonas sp. B7T; 2, Pseudomonas sp. B6G; 3, Pseudomonas sp. B3C; 4, Pseudomonas sp. $\mathrm{B} 2 \mathrm{~A} ; \mathrm{5}$, Ralstonia eutropha $\mathrm{H} 850 ; 6$, Sphingomonas yanoikuyae Q1; 7, E. coli BL21(DE3); 8, Burkholderia sp. LB400. The results were obtained from two individual electrophoretic runs (lanes 1-3 and 4-8, respectively).

(a)

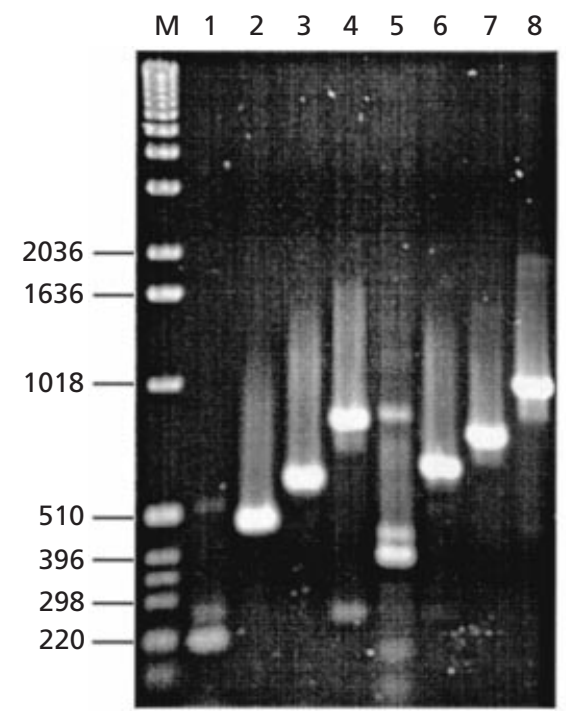

(b)

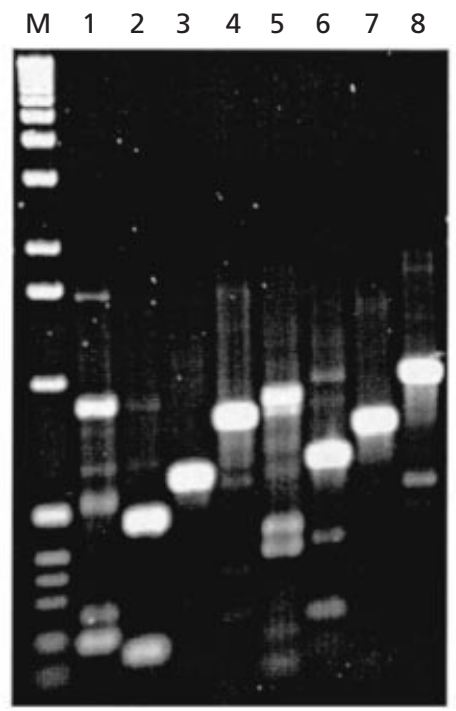

(c)

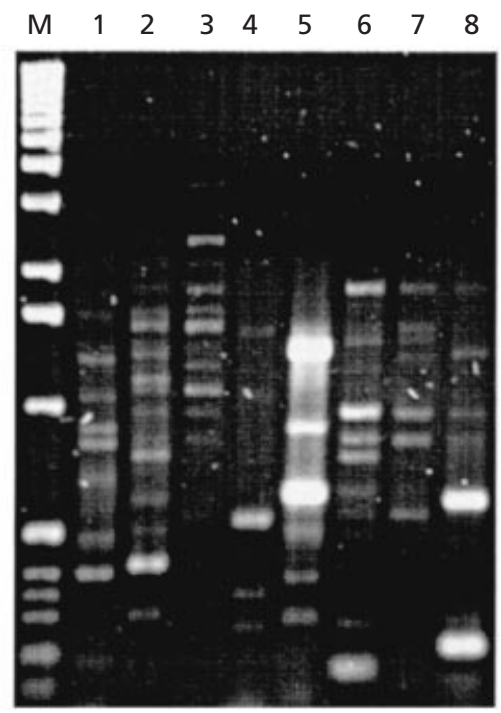

Fig. 6. Electrophoretic separation of PCR analyses of the presence of $b p h K$ and adjacent genes in different strains. (a) Burkholderia sp. LB400; (b) Pseudomonas sp. B6G; (c) Ralstonia sp. B11. Lanes: M, 1 kb DNA ladder (Gibco); 1, primer pair PK1 + PK2; 2, PK1 + PK3; 3, PK1 + PK4; 4, PK1 + PH1; 5, PC1 + PK2; 6, PC1 + PK3; 7, PC1 + PK4; 8, PC1 + PH1.

second, nested or semi-nested PCRs with primers PK1 and PK2. In one of these reactions, a fairly strong band of the mobility of the corresponding product from strain LB400 was obtained in addition to several other bands of comparable intensity (not shown). Sequencing of PCR products derived from strains $\mathrm{H} 850, \mathrm{~B} 3 \mathrm{~B}, \mathrm{~B} 4, \mathrm{~B} 7 \mathrm{~T}$ and B15 using primers PC1 and PK3 or PK1 and PK4 (Fig. 2) revealed $100 \%$ identity with the LB400 sequence in four cases. The $b p h$ sequence of Pseudomonas sp. strain B4, when compared to LB400, showed six silent or nonsilent point mutations and a deletion of 18 base pairs at the $3^{\prime}$ terminus of the $b p h C$ gene, but only three silent mutations at the $5^{\prime}$ end of the $b p h K$ gene (not shown).
The sequencing result with Ralstonia sp. strain B15 is remarkable with respect to the low efficiency of the PCRs and the weak signal obtained with the $b p h K$ probe. We rechecked the PCR results and exclude the formation of a false positive product due to contamination of the reaction mixture. Thus, we conclude that the weak annealing of the probe and probably also of the PCR primers was not due to a lack of complementary sequence. The effect could possibly be ascribed to rapid formation of stable secondary structures which mask the target sequence. Another puzzling result with the Ralstonia strains was their lack of BphK activity. A 1:1 mixture of extracts of strains B15 and LB400 yielded full 
BphK activity, thus ruling out the presence of an inhibiting activity in Ralstonia sp. strain B15. The possibilities that the $b p h K$ gene product does not accept $\mathrm{CDNB}$ or the presence of inactivating mutations can almost be ruled out since only nine terminal codons of the $b p h K$ gene of strain B15 have not been sequenced. Thus, the most likely explanation appears to be a lack of $b p h K$ expression.

\section{DISCUSSION}

Several lines of evidence indicate that the GSTs encoded by $b p h K$ and homologous genes are not absolutely required by aerobic bacteria for the utilization of $\mathrm{BP}$ as sole carbon source. The results presented in this work suggest that not all bacteria able to oxidatively degrade $\mathrm{BP}$ harbour a $b p h K$-like gene and/or synthesize a BphKlike GST in response to growth on this carbon source. They also showed that $\mathrm{BP}^{-}$mutants of strain LB400 that were also $b p h K^{-}$regained the ability to grow on $\mathrm{BP}$ as sole carbon source when complemented with a $b p h$ gene cluster lacking $b p h K$. Furthermore, it had been shown previously that E. coli BL21(DE3)[pLysS] harbouring genes $b p h A 1 A 2 A 3 A 4 B C D$, but devoid of $b p h K$ and of BphK activity (Hofer et al., 1994), was able to convert $\mathrm{BP}$ and a wide range of mono- to trichlorinated BPs into the corresponding benzoates (Seeger et al., 1995).

The finding that $b p h K$ is not absolutely required for utilization of BP does not exclude a usefulness of the gene. Without being essential, a gene that leads to even only a slight increase in growth rate or viability can give a large competitive advantage to its host. Moreover, $b p h K$ could only be helpful - or even essential - under specific conditions which may, for example, require additional detoxification during BP metabolism. A $b p h K$ requirement could well depend on specific features of the organism's BP catabolism and may therefore be strain-specific, thus explaining the absence of the gene in a number of BP degraders. Some experimental results positively support a function of $b p h K$. Firstly, $b p h K$ genes are present in several different $b p h$ loci. Secondly, these genes possess a high degree of sequence identity. Thus, $b p h K$ genes encoding identical enzymes (as far as the sequence has been determined) have been found in $b p h$ clusters from six different organisms, including strain LB400. Five of these loci significantly deviate from each other outside the $b p h K$ region (our unpublished results). Thirdly, $b p h K$ is expressed and its expression is conditionally enhanced in response to the use of BP as carbon source.

Additional evidence against a by-chance occurrence of $b p h K$ genes comes from the finding that GST-encoding genes seem to be widely distributed among bacteria able to aerobically degrade different aromatic coumpounds. A closely related but distinct group of GSTs (Table 4) has recently been found to be encoded by several polyaromatic hydrocarbon ( $\mathrm{PAH})$-degrading bacteria, and three of the respective genes, gst of Sphingomonas paucimobilis EPA505 (Lloyd-Jones \& Lau, 1997), phnC of Pseudomonas sp. strain DJ77 (GenBank accession number AF001103) and $b p h K$ of plasmid pNL1 of Sphingomonas aromaticivorans F199 (GenBank accession number AF079317) have been entirely sequenced. One of the gene products has been shown to accept CDNB as substrate (Lloyd-Jones \& Lau, 1997), and, on the basis of the high similarities in the sequenced regions, this is very likely to also hold for the rest of these GSTs. Their genes, like the LB400-type bphK genes, typically appear to be located at a similar, unique position within a certain type of gene cluster. Their downstream neighbours have invariably been identified as encoding a hydrolase (e.g. phnD, an analogue of

Table 4. Percentage sequence identity of bacterial GSTs possessing a relatively high similarity to Burkholderia sp. LB400 BphK

BphH-Haein, BphH of Haemophilus influenzae Rd; Gst-Ochan, Gst of Ochrobactrum anthropi; Gst-Escco, Gst of Escherichia coli K-12; GstB-Promi, GstB of Proteus mirabilis AF2924; XylKCycol, XYlK of 'Cycloclasticus oligotrophus' RB1; BphK-Bursp, BphK of Burkholderia sp. LB400; Gst-Sphpa, Gst of Sphingomonas paucimobilis EPA505; PhnC-Psesp, PhnC of Pseudomonas sp. DJ77; BphK-Sphar, BphK of Sphingomonas aromaticivorans F199.

\begin{tabular}{|c|c|c|c|c|c|c|c|c|c|}
\hline & $\begin{array}{l}\text { BphH- } \\
\text { Haein }\end{array}$ & $\begin{array}{l}\text { Gst- } \\
\text { Ochan }\end{array}$ & $\begin{array}{l}\text { Gst- } \\
\text { Escco }\end{array}$ & $\begin{array}{l}\text { GstB- } \\
\text { Promi }\end{array}$ & $\begin{array}{l}\text { XYlK- } \\
\text { Cycol }\end{array}$ & $\begin{array}{l}\text { BphK- } \\
\text { Bursp }\end{array}$ & $\begin{array}{l}\text { Gst- } \\
\text { Sphpa }\end{array}$ & $\begin{array}{l}\text { PhnC- } \\
\text { Psesp }\end{array}$ & $\begin{array}{l}\text { BphK- } \\
\text { Sphar }\end{array}$ \\
\hline BphK-Sphar & 34 & 41 & 43 & 44 & 49 & 54 & 84 & 90 & - \\
\hline PhnC-Psesp & 34 & 43 & 43 & 45 & 49 & 54 & 82 & - & \\
\hline Gst-Sphpa & 33 & 42 & 42 & 42 & 48 & 55 & - & & \\
\hline BphK-Bursp & 34 & 46 & 49 & 48 & 61 & - & & & \\
\hline XyIK-Cycol & 29 & 40 & 42 & 42 & - & & & & \\
\hline GstB-Promi & 29 & 36 & 54 & - & & & & & \\
\hline Gst-Escco & 32 & 39 & - & & & & & & \\
\hline Gst-Ochan & 29 & - & & & & & & & \\
\hline BphH-Haein & - & & & & & & & & \\
\hline
\end{tabular}


$b p h D)$ and an extradiol dioxygenase (e.g. phnE, an analogue of $b p h C)$ that are possibly involved in $\mathrm{PAH}$ catabolism (Lloyd-Jones \& Lau, 1997; Shin et al., 1997). Upstream adjacent genes have thus far only been desribed for $b p h K$ of strain F199. Based on sequence similarity, they encode the large and small subunits of an aromatic-ring hydroxylating mono- or dioxygenase. We note that, similar to the situation with BP degraders, gene clusters encoding PAH degradative pathways exist that are structured differently from the $p h n$-type cluster and probably do not contain a GST-encoding gene (e.g. the nah cluster of the prototype plasmid NAH7; Eaton, 1994). This suggests that such a gene is not generally required for PAH utilization. The first member of another closely related, but distinct, group of GSTs appears to be XylK of 'Cycloclasticus oligotrophus' RB1 (Table 4), a marine $\gamma$-proteobacterium that grows on several aromatic hydrocarbons including toluene, BP, naphthalene and phenanthrene (Wang et al., 1996). XylK accepts CDNB and is encoded by a gene which is also located in the vicinity of genes that, based on their sequences, are very likely to be involved in aromatic hydrocarbon metabolism, although their substrates are presently not known (Wang et al., 1996). The genetic environment of $x y l K$ is clearly different from those of $b p h K$ - and of $p h n C$-type genes. Recently, the gene gst of a CDNB-accepting GST with a high degree of sequence similarity to BphK of strain LB400 (Table 4) has been detected in the soil bacterium Ochrobactrum anthropi (Favaloro et al., 1998b), which is able to use the heteroaromatic herbicide atrazine as sole carbon source (Favaloro et al., 1998a). However, nothing is yet known about its genetic context. The soil bacteria Burkholderia cepacia AC1100, Sphingomonas sp. strain RW1 and Sphingomonas sp. strain RW5 are able to aerobically degrade 2,4,5-trichlorophenoxyacetate, dibenzodioxin and BP, or gentisate, respectively (Daubaras et al., 1996; Armengaud \& Timmis, 1997; Werwath et al., 1998). Genes encoding members of the GST superfamily have also been discovered in gene clusters of these organisms that encode enzymes for the breakdown of these or other aromatic compounds. However, the sequences of these GSTs are rather dissimilar to one another and to the above-mentioned GSTs. In agreement with this result, the enzyme of strain R W1 appears not to accept CDNB (Armengaud \& Timmis, 1997).

Interestingly, proteins with a significantly higher sequence similarity to the $\mathrm{BphK} / \mathrm{PhnC} / \mathrm{XylK}$-type enzymes are encoded by GST genes of E. coli K-12 (Nishida et al., 1994), Proteus mirabilis AF2924 (Perito et al., 1996) and Haemophilus influenzae Rd (Fleischmann et al., 1995) (Table 4). It has been shown that the $P$. mirabilis and E. coli enzymes also catalyse GSH conjugate formation with CDNB (Di Ilio et al., 1988; Nishida et al., 1994). Whilst P. mirabilis not only occurs in the intestines of mammals, birds and reptiles, but is also found in soils and polluted waters, E. coli and $H$. influenzae are not soil bacteria. E. coli $\mathrm{K}-12$ has been shown to aerobically grow on some phenylpropionates (Burlingame \& Chapman, 1983), and gene clusters ( $b c a$, $m h p$ ) for their degradation have been identified (GenBank accession numbers D86239 and Y11070; Ferrandez et al., 1997). However, the GST gene of E. coli $\mathrm{K}-12$ is neither part of either of these gene clusters nor are the genes flanking it related to catabolic functions. The latter is also the case for the GST genes found in $P$. mirabilis and $H$. influenzae. Thus the locations of these genes yield no clues to their roles. Their products could be ancient enzymes that belong to, for example, the catabolism of aromatic amino acids. $b p h K / p h n C / x y l K-$ type genes may have evolved from them in order to fulfil an analogous function in the breakdown of other aromatics such as biphenyls or PAHs. The low sequence similarity between the BphK/PhnC/XylK-type enzymes and the other GSTs encoded in gene clusters for the degradation of aromatic compounds could be explained if the latter enzymes have been derived from another class of ancient GSTs. Given the great versatility of GSH as a reagent and, consequently, of the reactions catalysed by the members of the GST superfamily (Vuilleumier, 1997), these other GSTs may differ in function from the BphK/PhnC/XylK-type enzymes, although they probably are also involved in the catabolism of aromatics.

Finally, we have shown that BphK of strain LB400 is a physically fairly stable protein that is active under a variety of conditions ranging, for example, up to at least $1 \mathrm{M}$ in salt concentration and up to $60^{\circ} \mathrm{C}$ in temperature. Moreover, the product of the reaction catalysed with the artificial substrate CDNB appeared not to be further metabolized. These results, together with the finding that $b p h K$ is co-expressed with other $b p h$ genes, make $b p h K$ and its analogues interesting candidates for the use as reporters for the monitoring of expression of gene clusters encoding such degradative pathways. This is of particular interest in cases when the activity of the commonly used extradiol-cleaving dioxygenases cannot be measured accurately or at all due to, for example, rapid further conversion of the cleavage product or to instability of the enzyme. We encountered such problems with several strains used in this study (cf. Table 2). Whilst the dioxygenases will remain extremely helpful for analyses such as the screening of gene banks, due to the chromogenic nature of the catalysed reaction, the BphK assay has, in our hands, largely replaced the $\mathrm{BphC}$ assay in the quantification of $b p h$ gene expression.

\section{ACKNOWLEDGEMENTS}

The authors are grateful to Petra Blumenroth and Irene Wagner-Döbler for gifts of BP-utilizing strains and acknowledge the technical assistance of Annette Krüger with rDNA sequencing.

\section{REFERENCES}

Altschul, S. F., Gish, W., Miller, W., Myers, E. W. \& Lipman, D. J. (1990). Basic local alignment search tool. J Mol Biol 215, 403-410.

Altschul, S. F., Madden, T. L., Schäffer, A. A., Zhang, J., Zhang, Z., Miller, W. \& Lipman, D. J. (1997). Gapped BLAST and PSI-BLAST : a new generation of protein database search programs. Nucleic Acids Res 25, 3389-3402. 
Aoki, Y., Satoh, K., Sato, K. \& Suzuki, K. T. (1992). Induction of glutathione $S$-transferase $\mathrm{P}$-form in primary cultured rat liver parenchymal cells by co-planar polychlorinated biphenyl congeners. Biochem J 281, 539-543.

Arca, P., Rico, M., Brana, A. F., Villar, C. J., Hardisson, C. \& Suarez, J. E. (1988). Formation of an adduct between fosfomycin and glutathione: a new mechanism of antibiotic resistance in bacteria. Antimicrob Agents Chemother 32, 1552-1556.

Armengaud, J. \& Timmis, K. N. (1997). Molecular characterization of $\mathrm{Fdx} 1$, a putidaredoxin-type [2Fe-2S] ferredoxin able to transfer electrons to the dioxin dioxygenase of Sphingomonas sp. RW1. Eur J Biochem 247, 833-842.

Asturias, J. A., Eltis, L. D., Prucha, M. \& Timmis, K. N. (1994a). Analysis of three 2,3-dihydroxybiphenyl-1,2-dioxygenases found in Rhodococcus globerulus P6. J Biol Chem 269, 7807-7815.

Asturias, J. A., Moore, E., Yakimov, M. M., Klatte, S. \& Timmis, K. N. (1994b). Reclassification of the polychlorinated biphenyldegraders Acinetobacter sp. strain P6 and Corynebacterium sp. strain MB1 as Rhodococcus globerulus. Syst Appl Microbiol 17, 226-231.

Ausubel, F. M., Brent, R., Kingston, R. E., Moore, D. D., Seidman, J. D., Smith, J. A. \& Struhl, K. (1994). Current Protocols in Molecular Biology. New York: Wiley.

Bauchop, T. \& Elsden, S. R. (1960). The growth of microorganisms in relation to their energy supply. J Gen Microbiol 23, 457-469.

Bedard, D. L., Haberl, M. L., May, R. J. \& Brennan, M. J. (1987). Evidence for novel mechanisms of polychlorinated biphenyl metabolism in Alcaligenes eutrophus H850. Appl Environ Microbiol 53, 1103-1112.

Blocki, F. A., Ellis, L. B. M. \& Wackett, L. P. (1993). MIF proteins are theta-class glutathione $S$-transferase homologs. Protein Sci 2 , 2095-2102.

Blumenroth, P. (1997). Konstruktion gentechnisch modifizierter Mikroorganismen für den in situ-Abbau polychlorierter Biphenyle (PCBs) in Sediment. PhD thesis, Technical University of Braunschweig, Germany.

Board, P. G., Baker, R. T., Chelvanayagam, G. \& Jermiin, L. S. (1997). Zeta, a novel class of glutathione transferases in a range of species from plants to humans. Biochem J 328, 929-935.

Bopp, L. H. (1986). Degradation of highly chlorinated PCBs by Pseudomonas strain LB400. J Ind Microbiol 1, 23-29.

Bopp, L. H., Chakrabarty, A. M. \& Ehrlich, H. L. (1983). Chromate resistance plasmid in Pseudomonas fluorescens. J Bacteriol 155, 1105-1109.

Bradford, M. M. (1976). A rapid and sensitive method for the quantitation of microgram quantities of protein utilizing the principle of protein-dye binding. Anal Biochem 72, 248-254.

Burlingame, R. \& Chapman, P. J. (1983). Catabolism of phenylpropionic acid and its 3-hydroxy derivative by Escherichia coli. J Bacteriol 155, 113-121.

Catelani, D., Colombi, A., Sorlini, C. \& Treccani, V. (1973). 2Hydroxy-6-oxo-6-phenylhexa-2,4-dienoate: the meta-cleavage product from 2,3-dihydroxybiphenyl by Pseudomonas putida. Biochem J 134, 1063-1066.

Crawford, R. L. \& Frick, T. D. (1977). Rapid spectrophotometric differentiation between glutathione-dependent and glutathioneindependent gentisate and homogentisate pathways. Appl Environ Microbiol 34, 170-174.

Daubaras, D. L., Saido, K. \& Chakrabarty, A. M. (1996). Purification of 1,2-dioxygenase and maleylacetate reductase: the lower pathway of 2,4,5-trichlorophenoxyacetic acid metabolism by
Burkholderia capacia AC1100. Appl Environ Microbiol 62, 4276-4279.

Di Ilio, C., Aceto, A., Piccolomini, R., Allocati, N., Faraone, A., Cellini, L., Ravagnan, G. \& Federici, G. (1988). Purification and characterization of three forms of glutathione transferase from Proteus mirabilis. Biochem J 255, 971-975.

Di Ilio, C., Aceto, A., Allocati, N. \& 7 other authors (1993). Characterization of glutathione transferase from Xanthomonas campestris. Arch Biochem Biophys 305, 110-114.

Eaton, R. W. (1994). Organization and evolution of naphthalene catabolic pathways: sequence of the DNA encoding 2-hydroxychromene-2-carboxylate isomerase and trans-o-hydroxybenzylidenepyruvate hydratase-aldolase from the NAH7 plasmid. $J$ Bacteriol 176, 7757-7762.

Eltis, L. D., Hofmann, B., Hecht, H.-J., Lünsdorf, H. \& Timmis, K. N. (1993). Purification and crystallization of 2,3-dihydroxybiphenyl-1,2-dioxygenase. J Biol Chem 268, 2727-2732.

Erb, R. W. \& Wagner-Döbler, I. (1993). Detection of polychlorinated biphenyl degradation genes in polluted sediments by direct DNA extraction and polymerase chain reaction. Appl Environ Microbiol 59, 4065-4073.

Erickson, B. \& Mondello, F. (1992). Nucleotide sequencing and transcriptional mapping of the genes encoding biphenyl dioxygenase, a multicomponent polychlorinated-biphenyl-degrading enzyme in Pseudomonas strain LB400. J Bacteriol 174, 2903-2912.

Fahey, R. C. \& Sundquist, A. R. (1991). Evolution of glutathione metabolism. Adv Enzymol Relat Areas Mol Biol 64, 1-53.

Favaloro, B., Melino, S., Petruzzelli, R., Di Ilio, C. \& Rotilio, D. (1998a). Purification and characterization of a novel glutathione transferase from Ochrobactrum anthropi. FEMS Microbiol Lett 160, 81-86.

Favaloro, B., Tamburro, A., Angelucci, S., De Luca, A., Di llio, C. \& Rotilio, D. (1998b). Molecular cloning, expression and sitedirected mutagenesis of glutathione S-transferase from Ochrobactrum anthropi. Biochem J 335, 573-579.

Ferrandez, A., Garcia, J. L. \& Diaz, E. (1997). Genetic characterization and expression in heterologous hosts of the 3-(3hydroxyphenyl)propionate catabolic pathway of Escherichia coli K12. J Bacteriol 179, 2573-2581.

Fleischmann, R. D., Adams, M. D., White, O. \& 37 other authors (1995). Whole-genome random sequencing and assembly of Haemophilus influenzae Rd. Science 269, 496-512.

Fujita, M., Hanada, Y. \& Adachi, Y. (1994). Glutathione $S$ transferases in sarcocarp tissue of pumpkin fruit exposed to 2,4dichlorophenoxyacetic acid. Biosci Biotechnol Biochem 58, 1349-1350.

Furukawa, K., Matsumura, F. \& Tonomura, K. (1978). Alcaligenes and Acinetobacter strains capable of degrading polychlorinated biphenyls. Agric Biol Chem 42, 543-548.

Furukawa, K., Simon, J. R. \& Chakrabarty, A. M. (1983). Common induction and regulation of biphenyl, xylene/toluene and salicylate catabolism in Pseudomonas paucimobilis Q1. J Bacteriol 154, 1356-1362.

Grant, S. G. N., Jessee, J., Bloom, F. R. \& Hanahan, D. (1990). Differential plasmid rescue from transgenic mouse DNAs into Escherichia coli methylation-restriction mutants. Proc Natl Acad Sci USA 87, 4645-4649.

Gutell, R. R., Weiser, B., Woese, C. R. \& Noller, H. F. (1985). Comparative anatomy of 16S-like ribosomal RNA. Prog Nucleic Acid Res Mol Biol 32, 155-216.

Habig, W. H., Pabst, M. J. \& Jakoby, B. J. (1974). Glutathione S- 
transferases. The first enzymatic step in mercapturic acid formation. J Biol Chem 249, 7130-7139.

Hayes, J. D. \& Pulford, D. J. (1995). The glutathione $S$-transferase supergene family: regulation of GST and the contribution of the isoenzymes to cancer chemoprotection and drug resistance. Crit Rev Biochem Mol Biol 30, 445-600.

Henikoff, S. \& Henikoff, J. G. (1992). Amino acid substitution matrices from protein blocks. Proc Natl Acad Sci USA 89, 10915-10919.

Hofer, B., Eltis, D., Dowling, D. \& Timmis, K. N. (1993). Genetic analysis of a Pseudomonas locus encoding a pathway for biphenyl/polychlorinated biphenyl degradation. Gene 130, 47-55.

Hofer, B., Backhaus, S. \& Timmis, K. N. (1994). The biphenyl/ polychlorinated biphenyl-degradation locus $(b p h)$ of Pseudomonas sp. LB400 encodes four additional metabolic enzymes. Gene 144, 9-16.

van Hylckama Vlieg, J. E. T., Kingma, J., van den Wijngaard, A. J. \& Janssen, D. B. (1998). A glutathione $S$-transferase with activity towards cis-1,2-dichloroepoxyethane is involved in isoprene utilization by Rhodococcus sp. strain AD45. Appl Environ Microbiol 64, 2800-2805.

lizuka, M., Inoue, Y., Murata, K. \& Kimura, A. (1989). Purification and some properties of glutathione $S$-transferase from Escherichia coli B. J Bacteriol 171, 6039-6042.

Karlson, U., Dwyer, D. F., Hooper, S. W., Moore, E. R. B., Timmis, K. N. \& Eltis, L. D. (1993). Two independently regulated cytochromes P-450 in a Rhodococcus rhodochrous strain that degrades 2-ethoxyphenol and 4-methoxybenzoate. J Bacteriol 175, 1467-1474.

Lane, D. J. (1991). 16S/23S sequencing. In Nucleic Acid Techniques in Bacterial Systematics, pp. 115-175. Edited by E. Stackebrandt \& M. Goodfellow. Chichester: Wiley.

La Roche, S. D. \& Leisinger, T. (1990). Sequence analysis and expression of the bacterial dichloromethane dehalogenase structural gene, a member of the glutathione $S$-transferase supergene family. J Bacteriol 172, 164-171.

Lloyd-Jones, G. \& Lau, P. C. K. (1997). Glutathione $S$-transferaseencoding gene as a potential probe for environmental bacterial isolates capable of degrading polycyclic aromatic hydrocarbons. Appl Environ Microbiol 63, 3286-3290.

Maidak, B. L., Olsen, G. J., Larsen, N., Overbeek, R., McCaughey, M. J. \& Woese, C. R. (1997). The RDP (ribosomal database project). Nucleic Acids Res 25, 109-110.

Mannervik, B. (1985). The isoenzymes of glutathione transferase. Adv Enzymol Relat Areas Mol Biol 57, 357-417.

Masai, E., Katayama, Y., Kubota, S., Kawai, S., Yamasaki, M. \& Morohoshi, N. (1993). A bacterial enzyme degrading the model lignin compound $\beta$-etherase is a member of the glutathione $S$ transferase superfamily. FEBS Lett 323, 135-140.

Moore, E. R. B., Wittich, R.-M., Fortnagel, P. \& Timmis, K. N. (1993). $16 \mathrm{~S}$ ribosomal RNA gene sequence characterization and phylogenetic analysis of a dibenzo- $p$-dioxin degrading isolate within the new genus Sphingomonas. Lett Appl Microbiol 17, 115-118.

Morales, V. M., Bäckman, A. \& Bagdasarian, M. (1991). A series of wide-host-range low-copy-number vectors that allow direct screening for recombinants. Gene 97, 39-47.

Mullis, K. B. \& Faloona, F. (1987). Specific synthesis of DNA in vitro via a polymerase-catalyzed chain reaction. Methods Enzymol 155, 335-350.

Nishida, M., Kong, K.-H., Inoue, H. \& Takahashi, K. (1994).
Molecular cloning and site-directed mutagenesis of glutathione $S$ transferase from Escherichia coli. The conserved tyrosyl residue near the $\mathrm{N}$ terminus is not essential for catalysis. J Biol Chem 269, 32536-32541.

Nohynek, L. J., Suhonen, E. L., Nurmiaho-Lassila, E. L., Hantula, J. \& Salkinoja-Salonen, M. (1996). Description of four pentachlorophenol-degrading bacterial strains as Sphingomonas chlorophenolica sp. nov. Syst Appl Microbiol 18, 527-538.

Perito, B., Allocati, N., Casalone, E., Masulli, M., Dragani, B., Polsinelli, M., Aceto, A. \& Di Ilio, C. (1996). Molecular cloning and overexpression of a glutathione transferase gene from Proteus mirabilis. Biochem J 318, 157-162.

Pickett, C. B. \& Lu, A. Y. H. (1989). Glutathione S-transferases: gene structure, regulation, and biological function. Annu Rev Biochem 58, 743-764.

Prohaska, J. R. (1980). The glutathione peroxidase activity of glutathione S-transferases. Biochim Biophys Acta 611, 87-98.

Sambrook, J., Fritsch, E. F. \& Maniatis, T. (1989). Molecular Cloning: a Laboratory Manual, 2nd edn. Cold Spring Harbor, NY : Cold Spring Harbor Laboratory.

Seeger, M., Timmis, K. N. \& Hofer, B. (1995). Conversion of chlorobiphenyls into phenylhexadienoates and benzoates by the enzymes of the upper pathway for polychlorobiphenyl degradation encoded by the $b p h$ locus of Pseudomonas sp. strain LB400. Appl Environ Microbiol 61, 2654-2658.

Shin, H.-J., Kim, S.-J. \& Kim, Y.-C. (1997). Sequence analysis of the phnD gene encoding 2-hydroxymuconic semialdehyde hydrolase in Pseudomonas sp. strain DJ77. Biochem Biophys Res Commun 232, 288-291.

Simon, R., Priefer, U. \& Pühler, A. (1983). A broad host range mobilization system for in vivo genetic engineering: transposon mutagenesis in Gram negative bacteria. Biotechnology 1, 784-790.

Stoesser, G., Sterk, P., Tuli, M. A., Stoehr, P. J. \& Cameron, G. N. (1997). The EMBL nucleotide sequence database. Nucleic Acids Res 25, 7-13.

Studier, F. W. (1991). Use of bacteriophage T7 lysozyme to improve an inducible T7 expression system. J Mol Biol 219, 37-44.

Studier, F. W. \& Moffat, B. A. (1986). Use of bacteriophage T7 RNA polymerase to direct selective high-level expression of cloned genes. J Mol Biol 189, 113-130.

Taira, K., Hayase, N., Arimura, N., Yamashita, S., Miyazaki, T. \& Furukawa, K. (1988). Cloning and nucleotide sequence of the 2,3dihydroxybiphenyl dioxygenase gene from the PCB-degrading strain of Pseudomonas paucimobilis Q1. Biochemistry 27, 3990-3996.

Tanno, K. \& Aoki, Y. (1996). Phosphorylation of c-Jun stimulated in primary cultured rat liver parenchymal cells by a coplanar polychlorinated biphenyl. Biochem J 313, 863-866.

Toung, Y.-P. S., Hsieh, T.-s. \& Tu, C.-P. D. (1993). The glutathione $S$-transferase $D$ genes. A divergently organized, intronless gene family in Drosophila melanogaster. J Biol Chem 268, 9737-9746.

Vuilleumier, S. (1997). Bacterial glutathione $S$-transferases: what are they good for? J Bacteriol 179, 1431-1441.

Wang, Y. \& Lau, P. C. (1996). Sequence and expression of an isocitrate dehydrogenase-encoding gene from a polycyclic aromatic hydrocarbon oxidizer, Sphingomonas yanoikuyae B1. Gene $168,15-21$.

Wang, Y., Lau, P. C. \& Button, D. K. (1996). A marine oligobacterium harboring genes known to be part of aromatic hydrocarbon degradation pathways of soil pseudomonads. Appl Environ Microbiol 62, 2169-2173. 
Werwath, J., Arfmann, H.-A., Pieper, D. H., Timmis, K. N. \& Wittich, R.-M. (1998). Biochemical and genetic characterization of a gentisate 1, 2-dioxygenase from Sphingomonas sp. strain RW5. J Bacteriol 180, 4171-4176.

Williams, W. A., Lobos, J. H. \& Cheetham, W. E. (1997). A phylogenetic analysis of aerobic polychlorinated biphenyl-degrading bacteria. Int J Syst Bacteriol 47, 207-210.

Wittich, R.-M., Wilkes, H., Sinnwell, V., Francke, W. \& Fortnagel, P. (1992). Metabolism of dibenzo-p-dioxin by Sphingomonas sp. strain RW1. Appl Environ Microbiol 58, 1005-1010.
Woese, C. R., Gutel, R. R., Gupta, R. \& Noller, H. F. (1983). Detailed higher-order structure of $16 \mathrm{~S}$-like ribosomal ribonucleic acids. Microbiol Rev 47, 621-669.

Xinhua, J., Zhang, P., Armstrong, R. N. \& Gilliland, G. L. (1992). The three-dimensional structure of a glutathione $S$-transferase from the Mu gene class. Structural analysis of the binary complex of isoenzyme $3-3$ and glutathione at $2 \cdot 2-\AA$ resolution. Biochemistry 31, 10169-10184.

Received 6 April 1999; revised 15 June 1999; accepted 22 June 1999. 